\title{
Note on Two Unrecorded Plumularian Hydroids from the Plymouth Area.
}

\author{
By \\ James Ritchie, M.A., D.Sc., \\ Royal Scottish Museum, Edinburgh.
}

Confusion has reigned in the works of British authors as to the relationship between Plumularia catharina, Johns., and a more simple form, with unbranched stem, found, like the former, on many parts of the coast. Johnston and Hincks, and the majority of their successors, have recorded the simple form, where it was thought worthy of mention, as a "stemless variety" of the former; but examination of the type specimens of $P$. catharina in the British Museum has proved that a fundamental distinction exists between the two forms.* $P$. catharina is a branched species and bears on each side of a hydrotheca a pair of lateral sarcothecae; the other is a branchless, bristle-like form, bears on each side of a hydrotheca a single lateral sarcotheca, and has been long known as Antenella (or Plumularia) secundaria (Gmelin).

One of the most common of Plumularias in the Plymouth area, in a wide sense, is $P$. catharina, and in a recent paper $\dagger \mathrm{Mr}$. Crawshay records the "creeping variety" from many stations in the Outer Western Area of the English Channel, with the remarks that it occurred over the whole area, and that it was perhaps the most frequent of the two varieties, and was certainly the most flourishing in point of growth.

I have had the opportunity, thanks to Mr. Crawshay, of examining a few samples of the simple form, and find that it embraces two distinct species, which are different from $P$. catharina, and have not been recorded from the area. The most common of these is Antenella secundaria (Gmelin), distinguished by a simple stem, and by details of hydrotheca structure exceedingly like those of the erroneous figure of $P$. catharina given by Hincks in " British Hydroid Zoophytes," Plate LVI, Fig. $2 a$. It was found at Duke Rock in August, 1895, and was dredged in the

* See Ritchie, "Note on the Type Specimens of Plumularia catharina," etc., Proc. Roy. Physical Soc., Edinburgh, Vol. XIX, 1913, p. 1.

+ Crawshay, Journ. Marine Biol. Association, Vol. IX, 1912, pp. 279 and 330. 
Outer Western Area of the Channel at Station 37 (S. $41^{\circ}$ W. of Eddystone at distance of $17 \cdot 1$ miles) in 1906 .

The other species is Antenella siliquosa (Hincks), described by Hincks, from St. Peter's Port, Guernsey, in 1877,* and since recorded from only two areas: from S.W. of Toulon at a depth of 445 metres, and in the neighbourhood of Roscoff on the N.E. corner of France between 60 to 80 metres (Billard, 1907 and 1912). To these localities Plymouth material adds two more records, both in the Outer Western Area of the Channel. A few colonies were obtained from Station 80 , S. $16 \frac{1}{2}^{\circ} \mathrm{W}$. of Eddystone, 48.9 miles distant, at a depth of 51 fathoms; and a larger clump was dredged during Cruise VII at an undefined position between S. $17^{\circ}$ to $27^{\circ} \mathrm{W}$. of the Eddystone, at a depth between 49 and 53 fathoms.

The two species may be readily distinguished. Both have simple unbranched stems. A. secundaria closely resembles $P$. catharina in the details of structure, but has only one sarcotheca flanking each hydrotheca, in place of a pair; $A$. siliquosa has a wider and larger hydrotheca, but its distinctive feature lies in the lateral sarcothecæ, which occur one on each side of a hydrotheca, and have the even margin of the terminal section interrupted by a large wide embayment, a condition not recorded from any other species of Antenella.

* Ann. Mag. Nat. Hist., ser. 4, Vol. XIX, 1877, p. 148, Pl. 12, Figs. 2-6. 